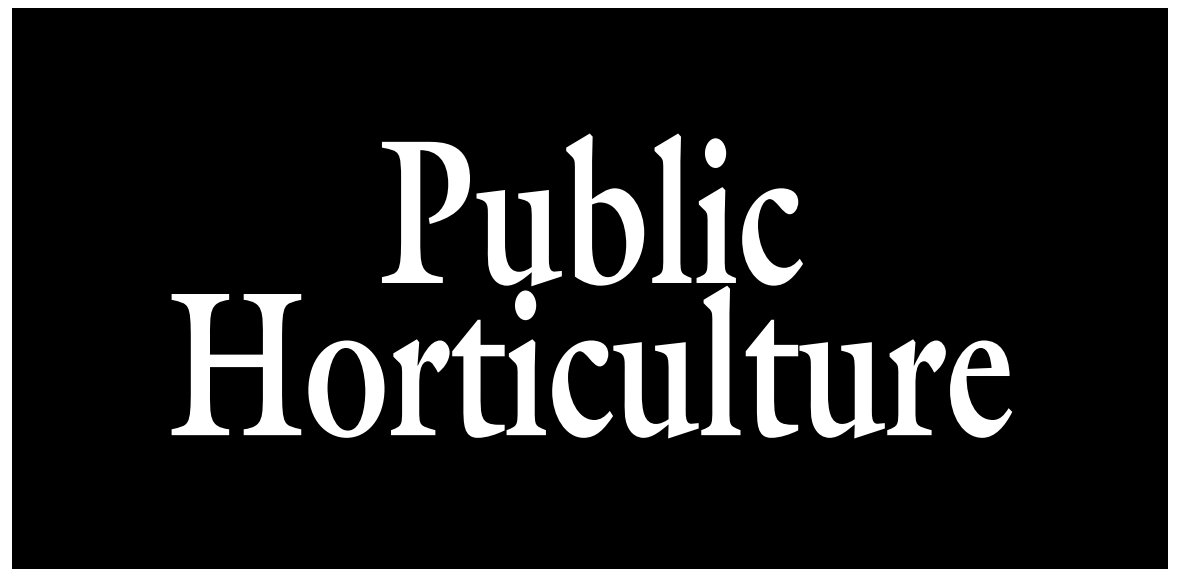

\section{Academic, Internship, and Cooperative Extension Programs at Botanic Gardens}

\author{
Mary Hockenberry Meyer ${ }^{1,3}$ and David Michener ${ }^{2}$
}

ADDITIONAL INDEX WORDs: arboreta, college students, Extension Master Gardeners, teaching

SUMMARY. Fifty-five online survey responses, 15 phone interviews, and 9 site visits were conducted to collect information on academic (for credit) classes, internships, and Cooperative Extension programs at botanic gardens and arboreta in the United States. Academic programs investigated were primarily instructional credit classes. Thirty-five (64\%) of the respondents indicated their garden offers an entire or partial academic class on-site. The most limiting factor in offering more academic classes was faculty time or staff limitations, as indicated by 21 participants $(38 \%)$. Thirty-one (56\%) gardens offer some type of internship, although only $16(30 \%)$ were offering an academic (for credit) internship. Respondents indicated extension involvement as follows: Extension Specialists/Extension Master Gardeners (EMG) teach classes on-site, 23 (42\%); EMG training was held on-site, 17 (31\%); EMG answered questions on-site, 16 (29\%); and 26 (47\%) indicated "other" extension collaboration. Sixty-six percent reported their working relationship with extension as minimal or fair as opposed to $33 \%$ who described their extension relationship as good to excellent. Examples of successful programs in these three areas are presented, which offer models for collaborative work between botanic gardens, academia, and extension.

$\mathrm{B}$ otanic gardens, Cooperative Extension, and land grant universities share a common goal of horticultural or plant science education. Many botanic gardens include education in their mission statements. While academic institutions typically offer formal programs culminating in a degree, botanic gardens and Cooperative Extension generally offer informal, avocational classes sometimes leading to a certificate or volunteer recognition, such as the EMG program.

${ }^{1}$ Department of Horticultural Science, MN Landscape Arboretum, University of Minnesota, St. Paul, MN 55108

${ }^{2}$ Matthaei Botanical Gardens and Nichols Arboretum, University of Michigan, Ann Arbor, MI 48105

${ }^{3}$ Corresponding author. E-mail: meyer023@umn.edu.
Cornell University and Cornell Plantations (Ithaca, NY), University of Delaware (Newark) and Longwood Gardens (Kennett Square, PA), University of Tennessee and University of Tennessee Gardens (Knoxville), and University of Washington with University of Washington Botanic Gardens (Seattle) offer graduate programs in public garden management, a relatively new and growing career area. Partnerships between academic institutions and botanic gardens attract new professionals to public horticulture and enable gardens and universities to fulfill their missions (Skelly and Hetzel, 2005).

Botanic gardens affiliated with academic institutions have advantages, such as the ability to offer a wide range of educational classes, along with university and community services. University gardens can unify the campus and create an entryway for the community into the university (Socolofsky and Burke, 2007); serve specific research, teaching, and experiential learning functions (Lewis and Affolter, 1999); become a living classroom (Scoggins, 2010); and increase recognition among administrators (Zadik, 2011). In addition, university gardens can fulfill the university's outreach mission, provide a competitive edge in attracting students, and serve as a living museum (Rakow, 2011). University botanic gardens can synergistically complement the academic institutional mission, conduct conservation and plant collections research (Dosmann, 2007), engage the public through applied research (Meyer et al., 2010), and involve students in solving complex real-world problems (Polomski et al., 2003).

Despite these advantages, Raven (2006) noted academic institutions are not always a "congenial home" for botanical gardens as they compete for funding and may not be "accepted as an integral part of the university's function." Watson et al. (1993) concluded "even when affiliated with a university, few botanic gardens are well integrated with instructional programs." With teaching, research, and public service at the core of academia's mission, botanic gardens, even those with historic academic affiliations, may be questioned as to their relevancy and importance in contributing to these three areas (Klatt and Pickering, 2003). Academic botanic gardens face 
the challenge of justification not only to the public and community, but also their own internal organization (Byers et al., 2003). Farmer (2010) found academic botanic gardens could suffer from being positioned as a small part of a large organization.

With the growing number of academic botanic gardens, there are few studies of programmatic successes and examples for developing collaborations that strengthen both the botanic garden and the academic institution (DeBuhr, 2011). Welldeveloped collaborative programs between Cooperative Extension and botanic gardens are rare. New Hanover County Arboretum (Wilmington, NC) works collaboratively with 11 Cooperative Extension staff on-site; however, no studies could be found that provided a national analysis of Cooperative Extension and botanic gardens collaboration, even though their missions of teaching informal horticultural classes are quite similar. Student internships at botanic gardens, especially those with academic credit and formal programs, are also not well characterized or defined (Hird et al., 2007).

The objective of this investigation was to complete a qualitative and quantitative analysis of academic (credit) classes, internships, and Cooperative Extension programs at botanic gardens and arboreta in the United States. Specific goals were to define successful or model programs that could be promoted and replicated to increase collaborations between botanic gardens, academic institutions, and Cooperative Extension.

Table 1. Online survey developed in Zoomerang (Survey Monkey, Palo Alto, CA) with link sent to American Public Garden Association university section members in Sept. 2010.

1. What academic classes are offered at your garden/arboretum for college credit?

2. Describe how your garden/arboretum is used for credit classes? Control all that apply.

$\square$ Academic students use the gardens and plant collections for class sessions and laboratory work

$\square$ Classes are held in the meeting rooms of our garden/arboretum

$\square$ Students learn from demonstration projects they create using the gardens and grounds

$\square$ Other, please specify

3. Do you offer an internship for academic credit at your garden/arboretum?

$\square$ Yes

$\square$ No

$\square$ Other, please specify:

4. How long (mo.) is the academic internship?

5 . What makes the internship distinct from a regular staff position?

6. What is the most limiting factor for your garden offering more academic classes?

7. What programs do you offer in conjunction with Cooperative Extension? Control all that apply.

$\square$ Extension Master Gardener Training

$\square$ Extension Master Gardeners answer questions on site

$\square$ Extension Specialists or Master Gardeners teach classes on site

$\square$ Other, please specify

8. Are any garden/arboretum staff members funded by Cooperative Extension?

$\square$ Yes, if so how many:

$\square$ No

9. How would you rate the interaction with Cooperative Extension and/or horticultural specialists at your garden or arboretum?

$\square$ None or minimal interaction

$\square$ Fair, 1-2 programs a year

$\square$ Good, we do 4-6 programs a year

$\square$ Excellent, we work together on a daily or weekly basis, our programs are stronger because of our close interworking relationship

10. Please add any further comments on academic or Cooperative Extension programs at your garden/arboretum:

11. Please give us your name, garden/arboretum and e-mail address to communicate these results with you. Thanks!

\section{Materials and methods}

On 9 Sept. 2010, the link to an online survey developed in Zoomerang (Survey Monkey, Palo Alto, CA) was sent to the 173 members of the university section of APGA in an e-mail with a request to complete a 10-question survey on academic, internships, and Cooperative Extension programs at their garden (Table 1). A follow-up reminder e-mail was sent $\approx 2$ and 4 weeks after the original request. Botanic gardens with large or well-known academic or extension programs were individually contacted and asked to complete the survey, if they did not respond within the first month. Fifteen survey respondents with extensive or unusual extension, internship, or academic programs were contacted for in-depth telephone and online analysis: Garvin Woodland Gardens (Hot Springs National Park, AK), Filoli Gardens (Woodside, CA), Rancho Santa Ana Botanic Garden (Claremont, CA), State Botanical Garden of Georgia (Athens), Smith College (Northampton, MA), Arnold Arboretum (Boston, MA), Matthaei Botanic Gardens (Ann Arbor, MI), Missouri Botanic Garden (St. Louis), New York Botanic Garden (New York), Brooklyn Botanic Garden (Brooklyn, NY), Morris Arboretum (Philadelphia, PA), Scott Arboretum (Swarthmore, PA), Utah Botanical Center (Kaysville), Longwood Gardens, and University of Washington. An additional nine gardens were visited in person: University of California (Davis), Fairchild Tropical Botanic Garden (Miami, FL), Chicago Botanic Garden (Glencoe, IL), JC Ralston Arboretum (Raleigh, NC), University of North Carolina Botanic Garden (Asheville), University of North Carolina Botanic Garden (Chapel Hill), Sarah P. Duke Botanic Garden (Durham, NC), Cornell Plantations, and University of Tennessee. Botanic garden directors, education directors, and directors of internship or academic programs were interviewed at these gardens. Responses were compiled and summarized with clarification via e-mail or phone where necessary. Survey data were collected from Sept. 2010 through July 2011.

\section{Results}

Sixty-one participants completed the survey for a $35 \%$ response rate. For 
Table 2. Responses from American Public Garden Association university gardens section members to the survey question: What academic classes are offered at your garden/arboretum for college credit?

Horticulture: Education Youth through Horticulture; Herbaceous Plant

Identification $(6)^{z}$; Woody Plant Identification (6); Greenhouse Production;

Home or Introduction to horticulture (4); Landscape Design (3); Public Garden

Management (3); Permaculture

Ecology, Biology: Biology, Economic Botany, Botany, Ecology (2); Natural Resource

Ecology and Management; Conservation Biology, Local Flora

Forestry: Urban Forestry (2); Dendrology

Other: Leadership Training; Photography; Honors Seminar; Art and Design; Literature; Architecture; Food Fiber and Fulfillment; Engineering and Construction Management; Plantations Lecture Series; Architectural Drawing; Plants and Human Well-Being

${ }^{\mathrm{z}}$ Numbers in parenthesis indicate the number of responses to this topic; topics with no number received one response.

three gardens, multiple staff (three each at three gardens) responded to the survey. Only one response per garden was included in the final garden count and percentages; however, comments and responses to openended questions (academic classes and intern duties, for example) were included where applicable for all respondents. Therefore, 55 responses from 55 botanic gardens or arboreta in 28 states and two Canadian provinces were tallied for the numerical results.

Academic classes. Thirty-five $(64 \%)$ of the respondents indicated their garden offered a complete or partial academic or credit class; 20 $(36 \%)$ of the participants indicated their garden offered no academic classes. Most classes are centered on horticulture, landscape architecture, or ecology, although a diverse range of topics were listed by respondents (see Table 2). The question did not attempt to determine if the academic class was taught by garden staff or academic staff; therefore, no assessment can be made on the impact of garden staff time on academic classes.

When asked how the garden is used for credit classes, 48 respondents $(87 \%)$ indicated academic students use the gardens and plant collections for class sessions and laboratory work; $28(51 \%)$ indicated classes are held in the meeting rooms of the garden/ arboretum; 29 (53\%) checked that students learn from demonstration projects they create using the gardens and grounds; and 16 (29\%) supplied answers as "other." Other was explained as special projects and independent study, plant identification; plant propagation; greenhouse production; botany laboratories, ecology studies; 11 respondents indicated credit internship classes are offered.
The most limiting factor in offering more academic classes was faculty time or staff limitations, as indicated by 21 participants $(38 \%)$. An additional six people indicated they had no faculty or were not an academic unit that could offer credit classes, and six more indicated their university had no horticulture program. Additional limitations and number of responses were: location or distance to campus 9 (16\%), lack of resources $9(16 \%)$, space/no rooms $6(11 \%)$, lack of priorities $3(5 \%)$, and no parking $\mathrm{l}(2 \%)$.

INTERNSHIPS. Sixteen (30\%) of the participants indicated their garden offered academic credit internships, whereas slightly more, $23(39 \%)$ indicated that they were not offering this type of internship. Fifteen (27\%) responded to the "other" category, stating they offer internships, but not for academic credit, or by special arrangement only. Therefore, 31 gardens $(56 \%)$ were offering something identified as an internship, regardless of academic credit. Some indicated they could not offer academic credit for paid internships.

The term "internship" was not defined in the survey; however, in asking if the internship was for academic credit, we felt the responses would show the academic linkage. When asked the length of the internship, of the 42 responses, 13 (37\%) indicated 3-5 months and the remainder indicated varying times from 2 to 12 months.

When asked how the internship varied from paid staff, participants showed a range of responses as follows: "The internship is a planned learning opportunity; interns rotate among specific garden areas to learn a variety of tasks; interns are involved with workshops and special training events, seminars, field trips and staff meetings; our Park, Recreation and Tourism Internship is in the visitor services area (Clemson University, Clemson, SC); group projects, individual projects, reflection papers and articles for the media are required of our interns; interns have a writing requirement; $25 \%$ to $50 \%$ of their time involves direct training, teaching; interns do more diverse work than regular employees; $1 \mathrm{~d}$ per week is spent learning an in-depth topic or public garden management issue; we have high and different expectations for interns; interns have focused projects and sometimes new projects that the garden has not done before; student interns must work in the plant clinic; interns must enroll in a graduate course (Morris Arboretum); interns must do a project and then a presentation, the advisor and garden supervisor oversee each intern's special report or project; interns are taught a broad range of skills; interns do in-depth work with a special staff member-curator, educational exhibition, etc."

EXTENSION PROgRAMS. When survey participants were asked: "What programs do you offer in conjunction with Cooperative Extension (check all that apply)," respondents indicated the following: Extension Specialists/EMG teach classes on-site at 23 (42\%), EMG Training 17 (31\%), EMG answer questions on-site 16 (29\%), and 26 (47\%) indicated "other." Other was defined as: Junior Master Gardener (JMG) uses garden site or JMG is taught here 7 (13\%), general tours, topic speakers, EMG are garden volunteers, programs for mentally challenged, $4 \mathrm{H}$, none, "we are not the land grant university," "our garden staff teach for extension." When asked "How would you rate the interaction with Cooperative Extension and/or horticultural specialists at your garden or arboretum?" participants indicated: fair, $1-2$ programs a year, 18 (37\%); none or minimal interaction, 14 (29\%); excellent, we work together on a daily or weekly basis, our programs are stronger because of our close interworking relationship, 10 (19\%); or good, we do 4-6 programs a year, 7 (13\%).

Very few botanic gardens staff are funded by Cooperative Extension. In this survey, only 6 (12\%) of the 50 
respondents to this question indicated extension funding supports garden staff. Positive responses were as follows: eight Cooperative Extension positions (Garvan Gardens), four extension positions (Utah Botanical Center), two extension positions (Missouri Botanic Garden), one extension position at two gardens, one partial extension position at one garden. The remaining $44(88 \%)$ participants who responded to this question indicated no financial support from extension for garden staff positions.

General comments on working with extension were: five respondents expressed an interest in working more with extension; one mentioned they are acutely underused by their university community. Other comments were: "we try not to compete with extension by offering different programs"; "Cooperative Extension is actually our biggest competition as they are able to offer courses that are similar to ours in content at a much lower cost"; "we have not been very successful at having them (extension) be more than tenants here." Many gardens indicated they offer educational programs taught by extension staff. Some respondents specifically said they had little interaction with extension and that extension had different goals and objectives. A few people spoke openly about "turf" issues and competing programs, being careful not to offer what would overlap with extension's classes.

\section{Discussion and recommendations}

ACADEMic Classes. Because survey participants were members of the APGA's university gardens section, it was expected that the majority of respondents would indicate their garden is used for academic classes. The diversity of class topics, especially at non-land grant institutions, was revealing, showing the application of plant science across disciplines. Faculty time or staff limitation was the reason most cited for not offering more academic classes, indicating a lack of human capital and perhaps priorities for academic programs. Offering academic classes requires the botanic garden to have a partnership with an academic institution, and although many of the respondents have this in place, they were still not offering the classes. Geographic distance between the botanic gardens and their academic partner was another limiting factor for more academic programs; however, Garvan Woodland Gardens and University of Arkansas address this challenge with summer school and Elderhostel programs (Byers, 1999).

EXAMPLES OF ACADEMIC Programs. Ackland Art Museum, University of North Carolina integrates university students with their on-campus museum by engaging faculty and students in determining which visual materials are displayed and how they are interpreted. Online information is ready to use for museum field trips, complete with methods and study questions. Regular e-mails to faculty remind them of ways to use the museum.

Matthaei Gardens and Nichols Arboretum, University of Michigan actively recruits and engages faculty and student programs in all disciplines that express or use the gardens' vision, collections, or landscapes. Active projects span architecture, art and design, dance, engineering, English, information sciences, landscape architecture, museum studies, pharmacy, and the expected natural sciences. In addition, it annually offers three endowment-generated student awards (each $\$ 500$ to $\$ 2000$ ) to acknowledge projects that meet the garden's goals in specific areas: women and environmental justice, environment studies in general, and systematic botany. Available online are past research projects with links to publications and further information (Matthaei Gardens, 2013).

Morris Arboretum, University of Pennsylvania has increased student visitorship with: 1) free Saturday student bussing to the gardens; 2 ) preceptorials, small noncredit seminars, led by University of Pennsylvania faculty such as Water at the Morris Arboretum: Time, Technology, and Topography or An Early Spring Escape to Morris Arboretum!; and 3) meeting with specific student groups on campus to encourage meeting and awareness of the arboretum. A University of Pennsylvania alumnus, who discovered the arboretum after graduation, provided partial funding for the above projects with the goal of integrating students into the arboretum.

Scott Arboretum at Swarthmore College stages programs throughout the year for their 1500 students: tours on Family and Alumni Weekends; rose-pinning for seniors and a commencement gift of a plant named at the Scott Arboretum, such as virginia sweet spire (Itea virginica 'Henry's Garnet'). Incoming students are invited to an open house and given a plant for their residence hall rooms, a longstanding tradition held each August.

Smith College Botanic Garden offers a Curriculum Enhancement Program, a competitive faculty stipend that encourages all faculty to use the botanic garden and plants as pedagogical tools (Zadik, 2011). Since 2007, a wide variety of classes (summarized online) have developed in dance, Chinese literature, child study, Spanish, Portuguese, art, and architecture. A specific endowment funds the program, which bridges the gap between the botanic garden and traditional academia. Smith also offers student internships on-site and at Royal Botanic Gardens (Kew, UK) funded through specific endowments.

University of California, Davis Arboretum considers every faculty a staff member of the arboretum and has a documented eight-page listing of classes or academic programs that have used the arboretum. The arboretum is adjacent to campus and provides an interface between the academic and urban communities. The GATEways project presented a new "Front Door" for the arboretum and the university (Socolofsky and Burke, 2007). The Oak Family Tree, a three-dimensional colorful mural on the exterior of an Arboretum building, was developed by University of California, Davis Art/ Science Fusion program. Based on academic findings (Pearse and Hipp, 2009), the artistic mural shows the evolutionary phylogenetic relationship of the arboretum's 29 oak (Quercus) species and the animals and insects associated with each species. The objective of the project was to develop an understanding of why insect herbivores interact with some introduced plant species more than others and to interpret this concept to the public through art installed at the arboretum.

INTERNSHIPS. Although a majority $(31,56 \%)$ of respondents indicated they were offering some kind of internship, it appears botanic gardens could make substantial educational gains in this area. Hird et al. 
(2007) found college advisors perceived public garden internships as less rigorous than the commercial horticulture industry, and proposed a set of national benchmarks or internship standards to assure consistency across the horticultural industry. Because $70 \%$ of our survey respondents indicated they were not offering an academic or credit internship, national standards could be beneficial for raising the stature of public garden internships while providing an outline for new internship programs. Students enrolled in an academic program may be able to arrange for internship credit through an independent or directed study course, if their institution does not offer a formal internship or professional experience class. To satisfy conflicts between credit and paid work, a specific time can be set aside weekly to meet the academic requirement of the internship. Success in providing and integrating an internship must be a priority of the botanic garden. The Morris Arboretum identifies their internship program as one of the highest priorities in their strategic plan (McFarlan, 2005) assuring the program's success.

On the basis of the survey respondents and in-depth interviews, we offer the following recommendations for internships. Be specific and clearly state what your internship offers: experience, salary, credit, academic value, job placement, etc. State your program expectations and encourage students to define their expectations and career interests. Document what defines a successful internship, with clear objectives and goals. Assure new interns are welcomed and informed about their work and academic expectations. Clothing, name tags, parking, breaks, and attendance policies should be explained in writing. Interns should feel welcome and part of the garden staff. Introduce interns at staff meetings and develop a clear meeting and academic schedule and timeline for project completion. Consider opportunities for interns to mentor youth from diverse backgrounds and incomes about college and horticultural careers. Develop interns' writing skills on the garden's Facebook (Menlo Park, CA) page, blog, or garden newsletter. Solicit project ideas from all staff and develop a list of specific projects for interns, tailored to their career interests. Develop a short video of internships to post on the garden's website. Culminate the program with public intern presentations on their projects where staff and donors are invited. Integrating interns into the mission and vision of the garden is critical for a successful internship program. Allowing interns to make suggestions for programmatic change can lead to transformational learning for students while advancing the garden's mission.

Students can bring a garden a fresh perspective in interpretation, marketing, and collection management while working as garden interns. Attracting young people to botanic gardens is a challenge; interns, especially academic students, can be part of the solution. Service learning opportunities can be developed by using the issues facing gardens while looking for solutions from the academic community. These interactions enhance student learning and increase the visibility of the garden, contribute to its overall mission, and strengthen academic relations (Polomski et al., 2003).

EXAMPLES OF INTERNSHIP PROGRAMs. Filoli Gardens has an extensive internship description, detailed learning program, and schedule for horticultural interns and apprentices. Its internship program is more extensive than some college credit internships.

Smith College and University of Delaware showcase their internships online with student photos and projects. Up-to-date online information can eliminate the lack of qualified applicants, one of the biggest challenges for internship programs (McFarlan, 2005).

Morris Arboretum offers a detailed list of specific internship tasks in their year-long, full-time with-benefits program with an educational emphasis in many areas including flora of Pennsylvania, plant protection, and urban forestry. The internship includes weekly seminars and practical sessions, field trips, work in plant clinic, and credit classes. Applicants must have an undergraduate degree and enroll in Issues in Arboretum Management, I and II, graduatelevel classes at University of Pennsylvania. Interns work directly with the living collections. A written and field identification examination as well as an oral and a written independent study project are required of each intern and are presented to the staff.

Longwood Gardens offers on-site housing for 22 interns. The 3 -month rotational summer internship is specifically for sophomore and junior horticulture students. Internships vary in length, from 3 to 12 months and include: all areas of the garden work, including curatorial; display design; library and archives; marketing and public relations; nursery management outdoor display; visitor programs; and performing arts. Longwood also offers international and high school internship programs.

Extension. Sixty-six percent of participants reported their working relationship with extension as minimal or fair, as opposed to $33 \%$ who described their extension relationship as good to excellent. Overall, across the United States, collaborations between extension and botanic gardens could be substantially increased. We expected botanic gardens of land grant universities to have a closer affiliation with Cooperative Extension specialists and educators; however, the survey results show this is not necessarily true. Cooperative Extension's mission is closely tied to land grant university research and is especially applicable to rural communities. The majority of the U.S. population now lives in suburban and urban areas, and may not be as familiar with extension.

Friends and garden centers supply gardening information, although the public perceives university and affiliated arboreta as more credible and trustworthy (Meyer and Foord, 2008). Although the Internet is an easy place to go for horticulture information, botanic gardens' prominent public image offers a distinct advantage for teaching horticulture. As noted, $42 \%$ of gardens offered classes taught by extension personnel, but only $29 \%$ offered EMG answering questions. Many botanic gardens appear to be missing an opportunity for collaboration with EMG to answer public horticultural questions, either on the garden's website or in person. A botanic garden or arboretum is one of the academic institution's "primary public faces that can generate public and political support for the institution" (Klatt and Pickering, 2003 ). 
Successful extension-botanic garden programs may also involve collaboration with the horticulture industry. Plant marketing programs, such as University of California, Davis's Arboretum All-Stars; Missouri's Plants of Merit; Plants Select at Denver Botanic Garden; and North Carolina's Wildflower of the Year, are examples of successful collaboration between extension programs, botanic gardens, and the industry that promote the best plants for local climates.

Demonstration gardens, plant trials, lawn management techniques, and sustainable gardening are examples of applied research that extension specialists can conduct at botanic gardens to showcase horticultural education in prominent public areas. Citizen Science, Project Budburst, and Bio Blitz are other educational programs that involve the public with academic and extension or outreach projects.

EXAMPLES OF EXTENSION PROGRAMs. Chicago Botanic Garden has a large outreach program with a Plant Info Desk, which answers $\approx 31,000$ questions annually and is staffed with 1.5 garden staff and 93 EMG. Chicago Botanic Garden has 220 EMGs that work at the Chicago Botanic Garden, their core training is provided by extension; however, Chicago Botanic Garden currently offers 16 classes for EMG only at a reduced price. Tailoring programs to the needs of the public, extension, and Chicago Botanic Garden's mission is key for the success of this collaboration.

In 1991, Missouri Botanic Garden, in collaboration with University of Missouri Extension, developed the Kemper Home Center, which functions as a county extension office inside the botanic garden. The center is managed by four program staff, one receptionist, six field horticulturists, and 200 EMGs and volunteers. This center's landscape includes 23 display or demonstration gardens covering 8 acres (3.2 ha). In 2009, the center had 123,284 visitors; 275 EMGs volunteered $31,166 \mathrm{~h}$ and answered 15,596 calls (Missouri Botanic Garden, 2013).

The Utah State University Botanical Center originated in 2002 "to guide the conservation and wise use of plant, water, and energy resources through researched-based educational experiences, demonstrations, and technology." The botanical center was formed with a wide group of key stakeholders, including Utah State University Cooperative Extension, UT State Office of Education, and Davis School District. Adjacent to a Utah Agricultural Experiment Station with extension staff housed on site, UT State University Botanical Center has been cited as an important teaching, research, and outreach arm of Utah State University (Utah Botanical Center, 2013).

\section{Conclusions}

We propose a paradigm shift in the traditional educational roles between botanic gardens and their academic partners, especially land grant institutions with Cooperative Extension. Extension's relevancy could be significantly increased by becoming more involved with botanical gardens and their education functions. As the number of gardens in academia has increased, it does not appear, from our survey and findings, that the interaction of the garden and academic community has fully developed. Farmer (2010) concluded successful strategies for relationshipbuilding involved well-developed systems of communication among partners, clearly defined and accepted roles and responsibilities, integrating the gardens into the mission of the academic institution, and sharing resources to achieve mutual goals. Additional considerations when developing new programs are the mission of the garden, its environmental features, location, the community, the collections, and staff strengths and weaknesses (DeBuhr, 2011). Determining the needs and incentives necessary for faculty or extension educator engagement is essential for lasting collaboration. On the basis of the findings of this survey, we propose the following three strategies as a framework from which to develop new academic, internship, or extension programs: 1) define and articulate the garden's mission and vision as it aligns with these areas; 2 ) identify personnel to lead the new programs while integrating with current offerings; and 3 ) understand and engage the academic and extension community in developing new programs.

A botanic garden offers a unique and beautiful space for public engagement and horticultural teaching.
Using resources and expertise of the academic and extension communities can enhance the garden and advance learning for students and the public in realizing the importance of plants in our lives.

\section{Literature cited}

Byers, R.D. 1999. Reaching out: A university botanical garden builds long-distance relationships. HortTechnology 9:573576.

Byers, B., G. Dreyer, R.C. Bumstead, G. Lee, R.E. Lyons, N. Doubrava, P.W. Meyer, and M. Zadik. 2003. College and university gardens: Profiles of seven diverse institutions. Public Garden 18:26-35.

Crane, P.R., S.D. Hopper, P.H. Raven, and D.W. Stevenson. 2009. Plant science research in botanic gardens. Trends Plant Sci. 14:575-642.

DeBuhr, L. 2011. Continuing, professional and higher education, p. 205-218. In: D. Rakow and S. Lee (eds.). Public garden management. Wiley, Hoboken, NJ.

Dosmann, M.S. 2007. The Arnold Arboretum's living collections: A repository for research. Arnoldia 65:30-39.

Farmer, J. 2010. Variations in types of major funding partnerships in college and university gardens. MS Thesis, Univ. Washington, Seattle.

Hird, A., G. Chapman, A. Hoffman, K. Leymaster, T. Boudreau, J. Gagliardi, C. Prestowitz, C. Sharber, A. Steil, S. Westervelt, and R. Lyons. 2007. The college horticulture internship experience: Promoting, growing and learning with students. Public Garden 22:34-37.

Klatt, B.J. and J. Pickering. 2003. Making the case for relevancy. Public Garden. $18: 8-9,36$.

Lewis, A.J. and J.M. Affolter. 1999. The state botanic garden of Georgia: A learning laboratory for student education. Hort Technology 9:570-572.

Matthaei Gardens. 2013. Internship descriptions. 4 June 2013. <http://sa.umich. edu/mbg/about/jobs_summerinternll. asp $>$.

McFarlan, J. 2005. The Morris Arboretum internship program: Training public garden managers for 26 years. Public Garden 20:32-34.

Meyer, M.H. and K. Foord. 2008. Consumer preferences and perceptions of gardening information. HortTechnology 18:162-167. 
Meyer, M.H., S. Hokanson, S. Galatowitsch, and J. Luby. 2010. Public gardens: Fulfilling the university's research mission. HortTechnology 20:522-527.

Missouri Botanic Garden. 2013. Kemper Center for Home Gardening. 20 May 2013. <http://missouribotanicalgarden. org/media/fact-pages/kemper-centerfor-home-gardening.asp $\mathrm{x}>$.

Pearse, I. and A. Hipp. 2009. Phylogenetic and trait similarity to a native species predict herbivory on non-native oaks. Proc. Natl. Acad. Sci. USA 106:1809718102.

Polomski, B., M.T. Haque, J. Arnold, and L. Wagner. 2003. Experiential edu- cation: Connecting universities and botanical gardens. Public Garden 18:2325.

Rakow, D. 2011. What is a public garden? p. 3-14. In: D. Rakow and S. Lee (eds.). Public Garden Management. Wiley, Hoboken, NJ.

Raven, P.H. 2006. Research in botanical gardens. Public Garden 1:16-17.

Scoggins, H. 2010. University garden stakeholders: Student, industry and community connections. HortTechnology 203:528-529.

Skelly, S. and C. Hetzel. 2005. The role of academic institutions in developing future leaders. Public Garden 20:1417.

Socolofsky, K. and M. Burke. 2007. The power of transformation: The life and times of a "learning organization." Public Garden 22:6-9.

Utah State University Botanical Center. 2013. About Us. 19 May 2013. <http:// usubotanicalcenter.org/htm/about-us $>$.

Watson, G., V. Heywood, and W. Crowley. 1993. North American botanic gardens. Hort. Rev. 15:1-62.

Zadik, M. 2011. Cultivating the academic community. Public Garden 25:21-24. 